\title{
Soil fertility status as influenced by the carryover effect of biochar and summer legumes
}

\author{
Hafeez ur Rahim ${ }^{* 1,2}$, Ishaq Ahmad Mian', Muhammad Arif ${ }^{3}$, Sajjad Ahmad ${ }^{3}$, Zaid Khan ${ }^{3}$ \\ ${ }^{1}$ Department of Soil \& Environmental Sciences, The University of Agriculture, Peshawar, Pakistan \\ ${ }^{2}$ School of Environmental sciences and technology, Dalian University of Technology, Liaoning, China \\ ${ }^{3}$ Department of Agronomy, The University of Agriculture, Peshawar, Pakistan
}

\begin{abstract}
Received:
May 26, 2019

Accepted:

November 09, 2019

Published:

February 17, 2020

\section{Abstract}

There are numerous benefits of biochar and summer legumes in the soil fertility status enhancement, so, keeping in consideration these benefits, a research study was designed to investigate the soil fertility status influence with the carryover effect of biochar and summer legumes at the UAP Research Farm, during winter 2016-2017. An experiment in the rotation was conducted in summer 2016 having three summer legumes for a specific purpose i.e. mungbean (grain), sesbania (green manuring), and cowpea (fodder), control was also comprised. Biochar synthesized domestically in a furnace from small wood cuttings on a pyrolysis temperature $\left(400-500^{\circ} \mathrm{C}\right)$ and applied once to legumes @0,5 and 10 tons ha ${ }^{-1}$. When the legumes were harvested, the residues of sesbania remained in the soil, while the residues of the other two legumes were taken away. The test for soil fertility status investigation was performed on subsequent wheat in RCBD with three replicates on the previous field layout of legumes. Significantly maximum soil total nitrogen, extractable $\mathrm{P}, \mathrm{K}, \mathrm{Fe}, \mathrm{Zn}, \mathrm{Mn}$ were obtained in the plots previously incorporated with sesbania. However, $\mathrm{Cu}$ was not significantly affected. While, in the case of preceding biochar, maximum soil total nitrogen, extractable $\mathrm{P}, \mathrm{K}$, $\mathrm{Cu}, \mathrm{Fe}, \mathrm{Zn}$, and $\mathrm{Mn}$ were obtained on 10 tons $\mathrm{ha}^{-1}$. The biochar-legumes interaction was significant for macronutrients while non-significant for micronutrients. Thus, it is concluded that preceding legumes and previously applied biochar showed a significant carry-over effect on soil fertility status.
\end{abstract}

Keywords: Biochar, Summer legumes, Soil fertility status

\section{How to cite this:}

Rahim HU, Mian IA, Arif M, Ahmad S and Khan Z, 2020. Soil fertility status as 8(1):11-16. DOI: 10.35495/ajab.2019.05.198

This is an Open Access article distributed under the terms of the Creative Commons Attribution 3.0 License. (https://creativecommons.org/licenses/by/3.0), which permits unrestricted use, distribution, and reproduction in any medium, provided the original work is properly cited.

\section{Introduction}

Declining soil fertility due to extensive agricultural practices is one of the most serious problem and obstacle to meet the increasing need for food supply and maximum yield of crops. Land degradation especially in terms of soil fertility/nutrients losses, severe climate change and food security problems indicating that the conventional farming system cannot be sustainable for the long-term (Gliessman, 2007). Problems related to soil degradation influencing round about 2 billion hectares soils across 
the world with severe consequences on food security, ecosystems services, agro-ecosystems resilience and global climate change (Lal, 2009). So, with these problems, the main challenge now a days is the restoration, conservation and improvement of soil quality and fertility. So, now, among the agricultural research community the inclusion of biochar, legumes and other cover crops as a climate smart agricultural practices in the cropping system gaining a great interest as a sustainable strategy to increase the growth and yield of crops by improving soil properties and fertility which resultantly increased the yield of crop and its productivity (Yamato et al., 2006).

In the early past, biochar, a carbon rich solid material which is synthesized by the process of pyrolysis from different types of biomass in the absence of oxygen is gained attention to enhance the quality of soil. The physicochemical properties of the biochar affect the function of biochar after addition to the soil system (Lehmann and Joseph, 2009). The important physical characteristics of biochar are its high porosity, low biodegradability and also having high surface area which can easily affect the nutrient retention in the soil (Spokas et al., 2012), moreover it can increase the fertility of soil because of its low decomposition rate (Steiner et al., 2007).

Similarly, nitrogen fertilizer is also essential and have an important role in soil fertility improvement, growth $\&$ yield of crops (Ogola et al., 2002), however, the excessive nitrogenous fertilizers application have several agricultural \& environment related problems like deterioration of soil health, yield decline, infiltration of $\mathrm{NO}_{3}^{-3}$ to the ground water causing abnormalities in infants \& also nitrous oxides \& ammonia volatilization which are huge global warming agents (Katyal et al., 2001). Considering these issues, it is needed to abase dependence on synthetic nitrogenous fertilizers and to integrate the legumes in cropping system to fix the atmospheric nitrogen and make possible its supply easy for 1 successful and fruitful crop production (Arif et al., 2014).

So, for this purpose, the combination of legumes (N source) and biochar ( $\mathrm{C}$ source) will help in decreasing 3 abundance on chemical nitrogen fertilizers and stimulate the legumes utilization, which is a good 4 . alternative for nitrogen supply to crops and hence getting higher production by balancing the $\mathrm{C}: \mathrm{N}$ ratio. So, in the present research study, three summer legumes crops, sesbania, mungbean and cowpea were sown in summer 2016 for the specific purposes. A fallow was adjusted in the experiment for the purpose of control. The rate of biochar addition was 0,5 and 10 tons/ha.

\section{Material and Methods}

\section{Experimental setup}

An experiment was conducted to examine the soil fertility status under the carry over effect of biochar and summer legumes at the UAP, Research farm in winter 2016-2017. A field trial in rotation was conducted during summer 2016 having three legumes crops \& grown for their specific purpose i.e. mungbean (grain), sesbania (green manuring), cowpea (fodder), and a control for comparison. Biochar prepared domestically in a furnaces from small wood cuttings with a pyrolysis temperature $\left(400-500^{\circ} \mathrm{C}\right)$ and added once to summer legumes @ 0, 5 and 10 tons/ha. When the legumes was harvested, the residues of sesbania was remained in the soil and residues of the remaining legumes were eliminated. The field trial for soil fertility investigations was conducted on subsequent wheat in RCBD two factor factorial arrangement with three replicates on the previous field lay out of summer legumes. The size of the plot was 13.5m x 4.2m \& Pir Sabaq-2013 was grown according to the recommended rate. Prior to start the work, the representative samples of the site have taken and measured for the selected soil fertility parameters as presented in table-1. Similarly, when wheat was harvested, soil samples in proper moisture condition were taken from every test unit and were analyzed for selected soil parameters like soil total nitrogen, extractable phosphorous, potassium, $\mathrm{Cu}, \mathrm{Fe}, \mathrm{Zn}$, and $\mathrm{Mn}$. All other agronomic practices were done according to the recommended procedures.

\section{Factor A: Legumes grown in summer Factor B: Biochar}

Mungbean were added for food grain

1. 0 tons ha ${ }^{-1}$ (control)

2. Cowpea for forage

2. 5 tons $\mathrm{ha}^{-1}$

Sesbania for green manuring

3. 10 tons $\mathrm{ha}^{-1}$

4. Fallow (control)

Soil total nitrogen $(\%)$

The measurement of total nitrogen in soil was done with the guidelines given by (Bremner, 1996). 
AB-DTPA Extractable phosphorous $(P)$, potassium $(\mathrm{K}), \mathrm{Zn}, \mathrm{Cu}, \mathrm{Mn}$ and $\mathrm{Fe}((\mathrm{mg} / \mathrm{kg})$

Extractable Phosphorous, potassium and micronutrients in soil was measured by the technique as illustrated by (Soltanpour and Schwab, 1977).

\section{Statistical analysis}

The data was carefully recorded and subjected to statistical analysis. Statistical tools used to analyse the data were described by Jan et al. (2009).

\section{Results}

The soil of the experimental site was alkaline in reaction, non-saline and low in soil nutrients content (phosphorous, total nitrogen and micronutrients).

Table 1. Soil nutrients status of the experimental site before sowing of summer Legumes.

\begin{tabular}{|c|c|c|}
\hline Property & Units & Concentration \\
\hline $\mathrm{pH}$ & - & 7.67 \\
\hline $\mathrm{ECe}$ & $\mathrm{dSm}$ & 0.14 \\
\hline Soil total nitrogen & $\%$ & 0.017 \\
\hline Extractable P & $\mathrm{mg} / \mathrm{kg}$ & 4.21 \\
\hline $\mathrm{K}$ & -- & 112 \\
\hline $\mathrm{Cu}$ & -- & 2.27 \\
\hline $\mathrm{Fe}$ & -- & 3.82 \\
\hline $\mathrm{Zn}$ & -- & 0.51 \\
\hline $\mathrm{Mn}$ & -- & 3.33 \\
\hline
\end{tabular}

Soil total nitrogen $(\%)$

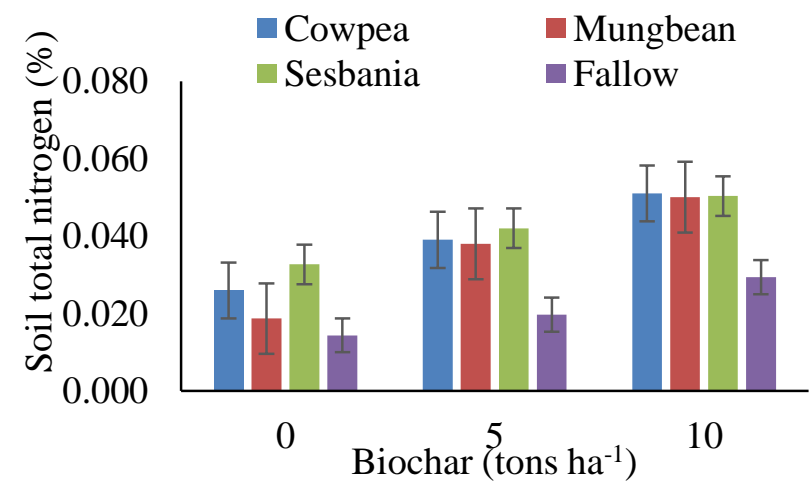

Fig 1. Soil total nitrogen (\%) as affected by carry over effect of biochar application and summer legumes

As shown in table-2, figure-1, mean values of the soil total nitrogen (STN) after wheat harvest revealed that previously grown legumes and biochar have significant effect on STN. The biochar-legumes interaction was also significant. The plots with sesbania incorporation had highest STN $(0.042 \%)$, followed by cowpea $(0.039 \%)$ and mungbean $(0.036$ $\%)$ which were statistically equal to each other, the lowest STN $(0.021 \%)$ was noted in fallow plots. In case of biochar, 10 tons/ha application rate increased STN $(0.045 \%)$ succeeded by 5 tons/ha $(0.035 \%)$, the lowest STN $(0.023 \%)$ was observed in control.

\section{Soil phosphorous (mg/kg)}

Statistics of the data concerning phosphorous $(\mathrm{P})$ after wheat harvest presented in table-2, figure-2, revealed that $P$ was significantly affected $(p \leq 0.05)$ by both treatments. Moreover, the biochar-legumes interaction was also significant. The highest $\mathrm{P}(8.0 \mathrm{mg} / \mathrm{kg})$ noted in the sesbania incorporated plots followed by cowpea $(6.8 \mathrm{mg} / \mathrm{kg}) \&$ mungbean $(6.3 \mathrm{mg} / \mathrm{kg})$, the lowest $\mathrm{P}$ $(5.8 \mathrm{mg} / \mathrm{kg})$ was noted in the fallow plots. The maximum P $(8.4 \mathrm{mg} / \mathrm{kg})$ obtained with biochar @ 10 tons $/$ ha succeeded by 5 tons $/ \mathrm{ha}(6.7 \mathrm{mg} / \mathrm{kg})$, the lowest $\mathrm{P}(5.1 \mathrm{mg} / \mathrm{kg})$ was noticed in control.

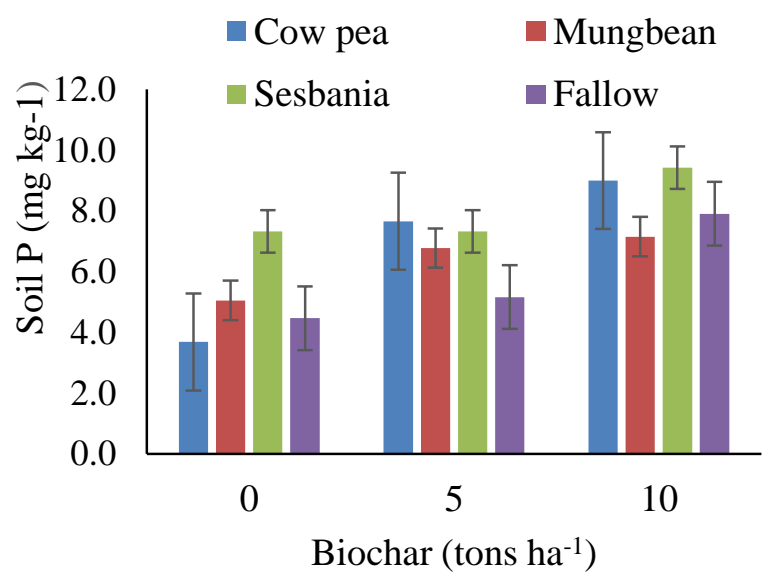

Fig 2. Soil $P$ (mg/kg) content as affected by carry over effect of biochar application and summer legumes.

\section{Soil potassium $(\mathrm{mg} / \mathbf{k g})$}

The data about potassium (K) after wheat harvest are given in table-2, figure-3. Mean values presented that the effect of both the treatments on soil $\mathrm{K}$ was significant. The interaction of biochar-legumes was also significant, but the $\mathrm{K}$ content was considerably affected by preceding legumes. The maximum $\mathrm{K}$ $(118.5 \mathrm{mg} / \mathrm{kg})$ obtained in the plots mixed with sesbania succeeded by cowpea $(116.5 \mathrm{mg} / \mathrm{kg})$ \& mungbean $(115.6 \mathrm{mg} / \mathrm{kg})$. The lowest $\mathrm{K}$ of 107.7 
$\mathrm{mg} / \mathrm{kg}$ was noticed in the fallow. With biochar effect, the highest $\mathrm{K}$ of $(119.8 \mathrm{mg} / \mathrm{kg})$ was obtained in the 10 tons/ha plots, succeeded by 5 tons/ha $(116.3 \mathrm{mg} / \mathrm{kg})$, the lowest $\mathrm{K}(107.7 \mathrm{mg} / \mathrm{kg})$ was obtained in the control.

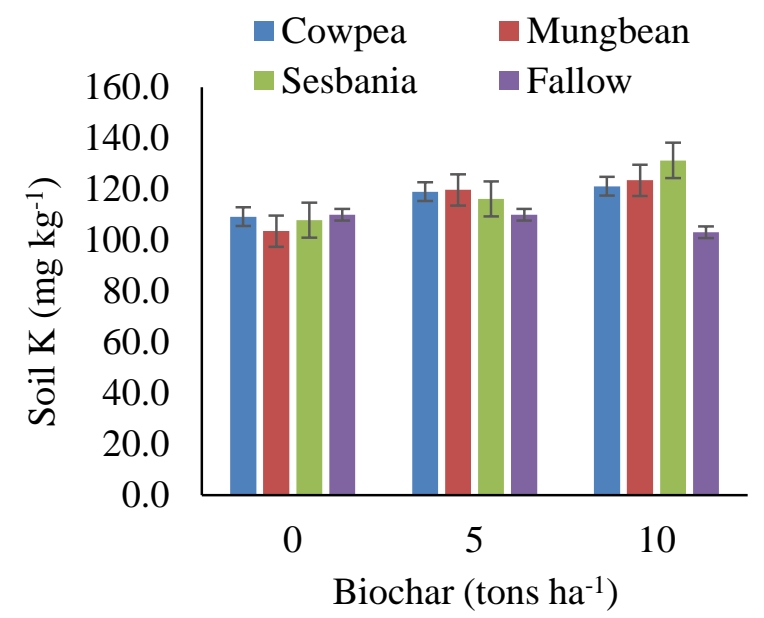

Fig 3. Soil K (mg/kg) content as affected by carry over effect of biochar application and summer legumes.

Table 2. Soil total nitrogen (\%), extractible $P$ and $\mathrm{K}(\mathrm{mg} / \mathrm{kg})$ as affected by residual effect of biochar application and summer legumes

\begin{tabular}{|c|c|c|c|}
\hline Legumes & Soil total N & Soil P & Soil K \\
\hline Cowpea & $0.039 \mathrm{ab}$ & $6.8 \mathrm{ab}$ & $116.5 \mathrm{a}$ \\
\hline Mungbean & $0.036 \mathrm{~b}$ & $6.3 \mathrm{~b}$ & $115.6 \mathrm{a}$ \\
\hline Sesbania & $0.042 \mathrm{a}$ & $8.0 \mathrm{a}$ & $118.5 \mathrm{a}$ \\
\hline Fallow & $0.021 \mathrm{c}$ & $5.8 \mathrm{~b}$ & $107.7 \mathrm{~b}$ \\
\hline LSD $(0.05)$ & 0.003 & 1.076 & 6.497 \\
\hline Biochar (tons ha $\left.{ }^{-1}\right)$ & & & \\
\hline 0 & $0.023 \mathrm{c}$ & $5.1 \mathrm{c}$ & $107.7 \mathrm{~b}$ \\
\hline 5 & $0.035 \mathrm{~b}$ & $6.7 \mathrm{~b}$ & $116.3 \mathrm{a}$ \\
\hline 10 & $0.045 \mathrm{a}$ & $8.4 \mathrm{a}$ & $119.8 \mathrm{a}$ \\
\hline LSD $(0.05)$ & 0.0030 & 0.932 & 5.626 \\
\hline Interaction & & & \\
\hline L x B & $*$ & $*$ & $*$ \\
\hline
\end{tabular}

Means followed by different letter(s) are significantly different at $\mathrm{P} \leq 0.05$

\section{Soil Zn (mg/kg)}

Statistics of the data presented that previous legumes and biochar significantly influenced soil $\mathrm{Zn}$ content (table-3). The interaction of biochar-legumes was insignificant. Sesbania mixed plots recorded increased soil $\mathrm{Zn}(0.60 \mathrm{mg} / \mathrm{kg})$ followed by cowpea $(0.58$ $\mathrm{mg} / \mathrm{kg}$ ) and mungbean $(0.54 \mathrm{mg} / \mathrm{kg})$, while the minimum $\mathrm{Zn}(0.52 \mathrm{mg} / \mathrm{kg})$ was noted in fallow, but the soil of experimental site under investigation was deficient in $\mathrm{Zn}$ content. The results were, however, inconsistent as no significant differences in soil $\mathrm{Zn}$ content were noticed between the legumes and fellow plots. Similarly, in case of biochar, 10 tons/ha application rate enhanced $\mathrm{Zn}(0.65 \mathrm{mg} / \mathrm{kg})$ after wheat harvest followed by 5 tons $/ \mathrm{ha}(0.56 \mathrm{mg} / \mathrm{kg})$. The minimum $\mathrm{Zn}(0.47 \mathrm{mg} / \mathrm{kg})$ was obtained in control.

\section{Soil Mn content $(\mathrm{mg} / \mathrm{kg})$}

The data representing the means values of soil $\mathrm{Mn}$ are shown in table-3. The trends in statistical data showing that both previous biochar application and preceding legumes have significant effect on soil $\mathrm{Mn}$. The biochar-legumes interaction was insignificant. The experimental units incorporated with sesbania noted maximum soil $\mathrm{Mn}(2.5 \mathrm{mg} / \mathrm{kg})$ followed by cowpea $(2.0 \mathrm{mg} / \mathrm{kg})$ and mungbean $(1.9 \mathrm{mg} / \mathrm{kg})$, while the minimum Mn $(1.7 \mathrm{mg} / \mathrm{kg})$ was obtained in fallow, but all the treatments results were statistically in line with each other. In case of biochar, 10 tons/ha application rate increased soil Mn $(2.6 \mathrm{mg} / \mathrm{kg})$ succeeded by 5 tons /ha $(2.0 \mathrm{mg} / \mathrm{kg})$. The minimum soil $\mathrm{Mn}(1.5 \mathrm{mg} / \mathrm{kg})$ was noted with 0 tons/ha biochar.

\section{Soil Fe content (mg/kg)}

The carry over influence of biochar and legumes on soil Fe are illustrated in table-3. Mean of the data presented that previous legumes and biochar have significant effect on soil Fe. The biochar-legumes interaction was insignificant. The plots incorporated with sesbania recorded maximum Fe content $(9.6$ $\mathrm{mg} / \mathrm{kg}$ ) followed by mungbean $(\mathrm{mg} / \mathrm{kg}$ ) and cowpea $(8.7 \mathrm{mg} / \mathrm{kg})$, while the minimum Fe $(7.1 \mathrm{mg} / \mathrm{kg})$ was obtained in the control. With biochar, 10 tons/ha application rate increased $\mathrm{Fe}$ content $(10.6 \mathrm{mg} / \mathrm{kg})$ after wheat harvest followed by 5 tons $/ \mathrm{ha}(8.7 \mathrm{mg} / \mathrm{kg})$, the lowest Fe $(6.6 \mathrm{mg} / \mathrm{kg})$ was obtained in the control.

\section{Soil $\mathrm{Cu}$ content $(\mathrm{mg} / \mathrm{kg})$}

Mean values of soil $\mathrm{Cu}$ given in table- 3 revealed that soil $\mathrm{Cu}$ was insignificantly influenced by legumes but biochar application significantly affected $\mathrm{Cu}$. The interaction of both treatments was also nonsignificant. Although significantly non-different, the plots incorporated with sesbania recorded highest $\mathrm{Cu}$ content $(2.0 \mathrm{mg} / \mathrm{kg})$ succeeded by mungbean $(1.8$ $\mathrm{mg} / \mathrm{kg}) \&$ cowpea $(1.7 \mathrm{mg} / \mathrm{kg})$, while the minimum $\mathrm{Cu}$ content $(1.6 \mathrm{mg} / \mathrm{kg})$ was recorded in the plots 
previously kept fallow. With biochar, 10 tons/ha application rate increased $\mathrm{Cu}(2.1 \mathrm{mg} / \mathrm{kg})$ after wheat harvest followed by 5 tons $/ \mathrm{ha}(1.7 \mathrm{mg} / \mathrm{kg})$. The minimum $\mathrm{Cu}(1.5 \mathrm{mg} / \mathrm{kg})$ was observed in the control.

Table-3: Soil $\mathrm{Zn}$ and $\mathrm{Mn}, \mathrm{Fe}$ and $\mathrm{Cu}(\mathrm{mg} / \mathrm{kg})$ as influenced by residual effect of biochar

\begin{tabular}{|c|c|c|c|c|}
\hline Legumes & $\begin{array}{c}\text { Soil } \\
\text { Zn }\end{array}$ & Soil Mn & Soil Fe & Soil Cu \\
\hline Cowpea & $0.58 \mathrm{a}$ & $2.0 \mathrm{ab}$ & $8.7 \mathrm{~b}$ & 1.7 \\
\hline Mungbean & $0.54 \mathrm{~b}$ & $1.9 \mathrm{~b}$ & $9.1 \mathrm{ab}$ & 1.8 \\
\hline Sesbania & $0.60 \mathrm{a}$ & $2.5 \mathrm{a}$ & $9.6 \mathrm{a}$ & 2.0 \\
\hline Fallow & $0.52 \mathrm{~b}$ & $1.7 \mathrm{~b}$ & $7.1 \mathrm{c}$ & 1.6 \\
\hline $\operatorname{LSD}(0.05)$ & 0.029 & 0.472 & 0.677 & ns \\
\hline \multicolumn{5}{|c|}{ Biochar (tons ha-1) } \\
\hline 0 & $0.47 \mathrm{c}$ & $1.5 \mathrm{c}$ & $6.6 \mathrm{c}$ & $1.5 \mathrm{~b}$ \\
\hline 5 & $0.56 \mathrm{~b}$ & $2.0 \mathrm{~b}$ & $8.7 \mathrm{~b}$ & $1.7 \mathrm{~b}$ \\
\hline 10 & $0.65 \mathrm{a}$ & $2.6 \mathrm{a}$ & $10.6 \mathrm{a}$ & $2.1 \mathrm{a}$ \\
\hline LSD (0.05) & 0.025 & 0.409 & 0.587 & 0.249 \\
\hline \multicolumn{5}{|l|}{ Interaction } \\
\hline $\mathrm{L} \times \mathrm{B}$ & $\mathrm{ns}$ & ns & ns & ns \\
\hline
\end{tabular}

Means followed by different letter(s) are significantly different at $\mathrm{P} \leq 0.05$

\section{Discussion}

The experimental results of the current research study indicated that soil fertility was significantly enhanced under the carry over effect of biochar and summer legumes. Biochar at rate of 10 tons/ha, while in case of legumes sesbania biomass showed a maximum significant carry over effect on selected soil fertility parameters. There are many possible reasons and mechanisms for the enhancement of soil fertility. Previously, Saraf and Patil, (1995) reported that incorporation and decomposition of green manuring legumes such as sesbania not only increased the yield of subsequent crop but also have a solubilizing effect on N, P and K. Our results are also in accordance with Jabbar et al. (2010) who reviewed that legumes crop when harvested leave a sufficient amount of nitrogen into the soil as residues. Similarly, Ghosh et al. (2007) reported that legumes play a very important role in solubilizing insoluble $\mathrm{P}$ in soil, enhancing the physical environment of soil, improving microbial activity in soil and restoring soil organic matter and also has smothering effect on weeds. Singh and Shivay, (2016) reported that the incorporation of sesbania aculeate residue supplied the maximum quantity of nutrients into the soil, that were comparably maximum than other green manuring crops.

With respect to biochar investigation Ali et al. (2015) reported that soil total nitrogen, phosphorous and potassium was significantly enhanced by biochar application over two years study. During first and second years of experiment changes was observed in soil total nitrogen with respect to application rates, while, the $\mathrm{P}$ and $\mathrm{K}$ was increased irrespective of biochar rate. Similarly, Matsubara et al. (2002) reported that biochar has the capability to promote soil $\mathrm{P}$ availability by enhancing michorizal association in which phosphorous is made available by fungi. Olmo et al. (2016) stated that patches along with high biochar content revealed low micronutrients availability in soil. Ali et al. (2015) published that biochar significantly increased yield of wheat and soil fertility in two years study under wheat-maize-wheat cropping system. Comparably, Rahim et al. (2019) published that biochar and legumes have pleasant effect on the physical properties of soil.

\section{Conclusion}

The results of the current work showed that both previously applied biochar and preceding legumes showed a significant carry over effect on soil fertility status. Especially, biochar @ 10 tons/ha and legume "sesbania" had a strong carryover effect on the soil fertility status. The interaction of biochar and legumes was significant for macro while non-significant for micronutrients. Further detail research is needed on farmers' fields at different locations and climatic zones in order to get more precise results.

\section{Acknowledgement}

The authors highly acknowledge Department of Soil and Environmental Sciences, UAP for supporting this research study.

Disclaimer: None.

Conflict of Interest: None. Source of Funding: None.

\section{References}

Ali K, Arif M, Jan MT, Khan MJ and Jones GL, 2015. Integrated use of biochar: a tool for improving soil and wheat quality of degraded soil under wheatmaize cropping pattern. Pak. J. Bot. 47(1): 233-240. 
Arif M, Jalal F, Jan MT and Muhammad D, 2014. Integration of biochar and legumes in summer gap for enhancing productivity of cereal based cropping system. Sarhad J. Agric. 30(4): 393-403.

Bremner JM, 1996. Nitrogen-total. Methods of Soil Analysis Part 3-Chemical Methods. pp. 1085-1121.

Ghosh PK, Bandyopadhyay KK, Wanjari RH, Manna MC, Misra AK, Mohanty M and Subba A R, 2007. Legume effect for enhancing productivity and nutrient use-efficiency in major cropping systemsan Indian perspective: a review. J. Sustain. Agric. 30(1): 59-86.

Gliessman SREd, 2007. Agroecology: the ecology of sustainable food systems, CRC Press, Taylor \& Francis, New York, USA. p.384.

Jabbar A, Ahmad R, Bhatti IH, Rehman A, Virk ZA and Vains SN, 2010. Effect of different rice-based intercropping systems on grain yield and residual soil fertility. Pak. J. Bot. 42(4): 2339-2348.

Jan MT, Shah P, Hollington PA, Khan MJ and Sohail Q, 2009. Agriculture Research: Design and Analysis, A Monograph. NWFP Agriculture University, Peshawar, Pakistan.

Katyal JC, Rao NH and Reddy MN, 2001. Critical aspects of organic matter management in the tropics: the example of India. In Managing Organic Matter in Tropical Soils: Scope and Limitations. Springer, Netherlands. pp. 77-88.

Katyal JCN, Rao H and Reddy MN, 2001. Critical aspects of organic matter management in the tropics. The Example of India. Nutr. Cycl. AgroEcosyst. 61(4):77-88

Lal R, 2009. Challenges and opportunities in soil organic matter research. Eur. J. Soil Sci. 60: 158169.

Lehmann J and Joseph S, 2009. Biochar for environmental management: an introduction. In: Lehmann J, Joseph S (eds). Biochar for environmental management: Science and Technology. Earthscan, London. pp. 1-10.

Matsubara Y, Hasegawa N and Fukui H, 2002. Incidence of Fusarium root rot in asparagus seedlings infected with arbuscular mycorrhizal fungus as affected by several soil amendments. J. Jap. Soc. Hort. Sci. 71(3): 370-374.

Ogola JBO, Wheeler TR and Harris PM, 2002. Effects of nitrogen and irrigation on water use of maize crops. Field Crop. Res. 78(2): 105-117.

Olmo M, Lozano AM, Barron V and Villar R, 2016. Spatial heterogeneity of soil biochar content affects soil quality and wheat growth and yield. Sci. Tot. Environ. 562: 690-700.

Rahim HU, Mian IA, Arif M, Rahim ZU, Ahmad S, Khan Z, Zada L, Khan MA and Haris M, 2019. Residual effect of biochar and summer legumes on soil physical properties and wheat growth. Pure Appl. Biol. 8:16-26

Saraf CS and Patil RR, 1995. Fertilizer use in pulse based cropping systems. Fertilizer News. 40: 5555.

Singh A and Shivay YS, 2016. Effect of summer green manuring crops and zinc fertilizer sources on productivity, Zn-uptake and economics of basmati rice. J. Plant Nutr. 39(2): 204-218.

Soltanpour PA and Schwab AP, 1977. A new soil test for simultaneous extraction of macro-and micronutrients in alkaline soils. Commun. Soil Sci. Plant. Anal. 8(3): 195-207.

Spokas KA, Cantrell KB, Novak JM, Archer DW, Ippolito JA, Collins HP, Boateng AA, Lima IM, Lamb MC, McAloon AJ and Lentz RD, 2012. Biochar: a synthesis of its agronomic impact beyond carbon sequestration. J. Environ. Qual. 41(4): 973-989.

Steiner C, Teixeira WG, Lehmann J, Nehls T, de Macêdo JLV, Blum WE and Zech W, 2007. Long term effects of manure, charcoal and mineral fertilization on crop production and fertility on a highly weathered central Amazonian upland soil. Plant Soil. 291(1-2): 275- 290.

Yamato M, Okimori Y, Wibowo IF, Anshori S and Ogawa M, 2006. Effects of the application of charred bark of Acacia mangium on the yield of maize, cowpea and peanut, and soil chemical properties in South Sumatra, Indonesia. Soil Sci. Plant Nutr. 52(4): 489-495.

\section{Contribution of Authors}

Rahim HU: Designed and performed experiment and analyzed data and manuscript write up Mian IA: Designed experiment and analyzed data Arif M: Designed experiment

Ahmad S: Performed experiment

Khan Z: Performed experiment 